\title{
Cytophaga aquatilis sp. nov., a Facultative Anaerobe Isolated from the Gills of Freshwater Fish
}

\author{
WILLIAM R. STROHL $\dagger$ AND LARRY R. TAIT $\dagger \dagger$ \\ Department of Biology, Central Michigan University, Mt. Pleasant, Michigan 48859
}

\begin{abstract}
A facultatively anaerobic, gram-negative, gliding bacterium was isolated from the gills of freshwater fish. Its deoxyribonucleic acid base composition ( $33.7 \mathrm{~mol} \%$ guanine plus cytosine), lack of microcysts or fruiting bodies, cell size ( 0.5 by 8.0 $\mu \mathrm{m})$, and hydrolysis of carboxymethylcellulose and chitin place it in the genus Cytophaga. This aquatic cytophaga is differentiated from other cytophagas by its fermentation of carbohydrates, proteolytic capabilities, and a number of additional physiological and biochemical tests. The organism was compared to other similar isolates reported from fish, and it appears to belong to a new species, for which the name Cytophaga aquatilis is proposed. The type strain of C. aquatilis, $\mathrm{N}$, has been deposited with the American Type Culture Collection under the accession number 29551.
\end{abstract}

Borg (3) described four strains of facultatively anaerobic cytophagas isolated from salmon at the Skagit Fish Hatchery near Seattle, Wash. He associated those strains with bacterial gill disease although their pathogenicity was not proven.

While studying "myxobacterial" diseases of salmonoids, Anderson and Ordal (2) isolated and studied a saprophytic fermentative cytophaga that required $\mathrm{CO}_{2}$ for the fermentation of glucose. They named the organism Cytophaga succinicans. Pacha and Porter (14) isolated and characterized a number of facultatively anaerobic strains of saprophytic cytophagas from salmon, and Anderson and Conroy (1) compared five strains of fermentative cytophagas to Borg's Skagit strains and again associated them with bacterial gill disease of salmon.

A recent study by Bullock (4) showed that certain cytophaga-like strains, including a group of facultatively anaerobic cytophagas, could be associated with bacterial gill disease as opportunistic invaders, but no single pathogenic species was found.

Trust (22) showed that cytophagas are a part of the normal gill flora in a number of both wild and hatchery-raised salmon, and he indicated that these organisms, along with pseudomonads, are the predominant species of bacteria on the gills of healthy salmon.

In this report, we describe a new facultatively anaerobic species of Cytophaga which was isolated from the gills of diseased salmon at the Platte River Fish Hatchery in Michigan. Our

† Present address: Dept. of Microbiology, Louisiana State University, Baton Rouge, LA 70803.

† Present address: Dept. of Microbiology, Wayne State University, Detroit, MI 48202. isolates are similar to those strains of facultatively anaerobic cytophagas described by Borg (3), Pacha and Porter (14), Anderson and Conroy (1), and Reichardt (16).

\section{MATERIALS AND METHODS}

Bacterial strains. Thirteen strains of cytophagas were isolated from diseased salmon or trout at the Platte River Fish Hatchery, Honor, Mich.; the Wolf Lake Fish Hatchery, Wolf Lake, Mich.; and from diseased suckers obtained from the holding tanks of an Honor, Mich., baitshop. The strains and their sources are listed in Table 1.

Methods. Three isolation methods were used to obtain the cytophagas: (i) salmon gills or fins were swabbed with sterile cotton swabs and streaked onto skim milk medium (6), CP medium (5), and Pate and Ordal medium (15); (ii) aseptically dissected gills or fins were placed onto CP or skim milk medium; and (iii) aseptically dissected gills were blended with 100 $\mathrm{ml}$ of sterile distilled water and plated onto $\mathrm{CP}$ and skim milk media. Isolates from the plates were obtained by picking the edges of spreading colonies and placing them onto plated Pate and Ordal medium containing 0.9 or $1.5 \%$ agar. Spreading colonies from these plates were checked for gliding motility. Gliding of cells was determined by the use of hanging-drop and wet-mount preparations and by observing plate or slide agar mounts under phase and light microscopy. A medium of $2 \%$ Casitone and Chu no. 10 basal salts (20) was used as a basal medium and a maintenance medium for the cytophagas throughout this investigation.

The temperature for optimal growth was determined by growing the cultures in liquid basal medium at various temperatures from 0 to $37^{\circ} \mathrm{C}$ and comparing the relative optical densities over a 2 -week period. Methods for the determination of lauryl sulfate tolerance, carboxymethylcellulose digestion, alginate liquefaction, and tyrosine degradation were those of Lewin and Lounsbery (12). The methods of Pacha and Porter (14) were employed for the determination of 
TABLE 1. Sources and strains of cytophagas isolated from fish in March 1974

\begin{tabular}{ccllc}
\hline $\begin{array}{c}\text { Strain desig- } \\
\text { nation }\end{array}$ & Group $^{a}$ & \multicolumn{1}{c}{ Source } & \multicolumn{1}{c}{ Type of fish } & $\begin{array}{c}\text { Location on fish } \\
\text { where obtained }\end{array}$ \\
\hline T & I & Platte R. Hatchery & Salmon \\
R & I & Platte R. Hatchery & Salmon & Gills \\
O & I & Honor, Mich., baitshop ${ }^{c}$ & Sucker & Gills \\
Q & I & Platte R. Hatchery & Salmon & Gills \\
N & I & Platte R. Hatchery & Salmon & Gills \\
A & II & Wolf Lake Hatchery & Atlantic salmon & Fills \\
B & II & Wolf Lake Hatchery & Atlantic salmon & Fins \\
D & III & Platte R. Hatchery & Trout & Fins \\
G & III & Platte R. Hatchery & Trout & Fins \\
P & IV & Wolf Lake Hatchery & Atlantic salmon & Fins \\
J & IV & Platte R. Hatchery & Salmon & Gills \\
K & IV & Wolf Lake Hatchery & Atlantic salmon & Fins \\
S & IV & Wolf Lake Hatchery & Atlantic salmon & Fins \\
\hline
\end{tabular}

${ }^{a}$ The group I strains are the strains which are discussed in detail in this paper.

${ }^{b}$ The species of the salmon or trout were not recorded.

' From holding tanks outside the baitshop.

gelatin liquefaction, catalase production, casein, starch, and esculin hydrolysis, digestion of chitin, and cytochrome oxidase production. Oxidation or fermentation of carbohydrates was determined by the production of acid in phenol red basal agar medium (Difco; 8) with $1 \%$ carbohydrate added. For the oxidation of carbohydrates, the acid reaction on plates of aerobically incubated cultures was recorded as positive. For the fermentation tests, sterile Vaspar was overlaid on agar deeps, and an acid reaction was considered as positive. Aerobic and anaerobic growth of the cultures was tested on $1 \%$ glucose supplemented with Chu no. 10 basal salts alone, basal salts plus $0.5 \%$ yeast extract, basal salts plus $0.5 \% \mathrm{KNO}_{3}$, and basal salts plus $0.1 \% \mathrm{NH}_{4} \mathrm{H}_{2} \mathrm{PO}_{4}$. The degradation of native cellulose was tested by placing sterile Whatman no. 1 filter paper disks onto plates containing Chu no. 10 basal salts and $0.1 \%$ yeast extract. The cellulose plates were incubated aerobically for a 4-week period, and positive results were recorded if dissolution of the paper occurred. Salinity tolerance was tested by placing $0.5,1.0,1.5,2.0,2.5,3.0,3.5$, and $4.0 \% \mathrm{NaCl}$ into the basal medium and observing growth over 2 weeks. All other physiological tests were done with standard procedures found in the Difco Manual (8), except those done with the Enterotube apparatus (BBL Products, Inc., Baltimore, Md.).

The ability of the cytophagas to lyse bacterial cells was examined by swabbing live cultures of various bacteria across non-nutrient agar plates and then stabbing the cytophaga test culture into the center. Positive results were indicated by dissolution of the bacterial colony with spreading of the cytophaga colony beyond the swabbed cultures of test bacteria. Lysis of cyanobacteria was tested by the methods described by Shilo (20) and by Gromov et al. (10); cultures of Plectonema boryanum, Anacystis nidulans, and Nostoc sp. were used as test cultures.

Antibiotic susceptibilities were determined by placing susceptibility disks of various antibiotics onto basal medium plates streaked with the Cytophaga cultures; positive results were indicated by zones of inhibition. (See Table 6 for strengths of the antibiotics and results of the susceptibility testing.)

Microcyst and fruiting-body production were deter- mined by the methods of Dworkin and Gibson (9) and by placing the culture onto yeast streaks and observing for fruiting structures over a 6 -week period. The $C y$ tophaga pigments were extracted with $100 \%$ acetone or $95 \%$ ethanol, and absorption curves were run on a Gilford 2400 recording spectrophotometer. Analysis and gross characterization of the pigments were accomplished by the methods of Reichenbach et al. (18).

For electron microscope observations of the colonies, frozen-surface replicas were prepared by the method of Steere (21) with cultures that were fixed for $1 \mathrm{~h}$ on plates of basal medium with $3 \%$ glutaraldehyde. The agar was sliced approximately $3 \mathrm{~mm}$ below the surface and placed onto stubs for insertion into the modified Denton DFE-2 freeze-etch unit. Replicas were shadowed at a $45^{\circ}$ angle with platinum-carbon and were carbon coated. Electron micrographs were taken, using a JEM 100B electron microscope equipped with a $60^{\circ}$ tilt goniometer stage. Thin sections were prepared by a modified Ryter-Kellenberger technique (19). Plates of cells grown on basal medium for $48 \mathrm{~h}$ were flooded with $0.02 \% \mathrm{OsO}_{4}$ for 20 to $30 \mathrm{~min}$, and the clumped bacteria were scraped off the agar and transferred to $1 \% \mathrm{OsO}_{4}$ for $18 \mathrm{~h}$. Acetone dehydration (using, in a series, 50,70, 85, 95, 100, and $100 \%$ acetone) and Mollenhauer no. 1 plastic embedding procedure (13) were followed, and thin sections of the cytophaga were obtained on a Sorvall MT-2 PorterBlum ultamicrotome with glass knives. Electron micrographs (magnification approximately $\times 40,000$ ) of thin sections of the cytophaga were taken by using a Phillips 300 electron microscope. Measurements of cell size were obtained with a Filar micrometer under phase microscopy using 24 -h-old liquid cultures.

\section{RESULTS}

The aquatic cytophaga reported here is a facultatively anaerobic bacterium that uses fermentable carbohydrates as suitable substrates for anaerobic growth. Growth factors in yeast extract or peptone are required for growth and fermentation of the carbohydrates, and anaerobic growth occurs only during fermentation or during nitrate reduction. 
A culture stabbed into $2 \%$ tryptone agar plates produced within 7 days a spreading colony with areas of purple, brown, yellow, and orange pigmentation. On peptone, Casitone, and nutrient agar media, colonies spread and were pigmented yellow to orange, whereas on skim milk and CP media the spreading colony was thinner and nearly colorless. Colonies from anaerobically grown cultures were a light cream color or nonpigmented. Nutrient concentrations between 0.1 and $2.5 \%$ and agar concentrations between 0.75 and $2.0 \%$ did not greatly affect the spreading ability of this organism. Motility of the cells was by gliding and no flagella were present. Copious amounts of slime were produced within spreading colonies (Fig. 1). The cells at the periphery of the colony radiated from the central region of the colony and were etched into the agar (Fig. 2). As observed in the frozen-surface replica (Fig. 2 ), ice crystals formed from free water were in direct contact with damaged cells, indicating hydrolysis of nutrients in the medium immediately adjacent to the cells. On media containing low nutrient concentrations, motile (rotating) microcolonies were formed which were connected by tracks of slime left behind by gliding clumps of cells.

Five of the 13 strains isolated were able to hydrolyze chitin only weakly or not at all, and they did not hydrolyze cellulose under aerobic conditions. They did not produce indole or $\mathrm{H}_{2} \mathrm{~S}$ or utilize citrate as a sole carbon source, but they did produce catalase aerobically, hydrolyze starch and gelatin, reduce nitrate to $\mathrm{NH}_{3}$, grow anaerobically on glucose and yeast extract, and produce identical pigments and colonial morphologies (Table 2). Cells of all five strains measured 5 to $15 \mu \mathrm{m}$ in length (average, $8 \mu \mathrm{m}$ ). They occurred singly and did not produce sheaths or filaments. Degenerate coccoid forms and spheroplasts were found in both young and old cultures although they were more prevalent in the older cultures. The coccoid forms were examined by electron microscopy and were found to be shortened rods rather than microcysts. Fruiting bodies were not formed.

Because the five group I strains (Table 1) were so nearly identical morphologically and physiologically, only one strain $(\mathrm{N})$ was studied further to elucidate the specific characteristics of the group. The physiological and biochemical characteristics of strain $\mathbf{N}$ are given in Table 3 , and the morphological characteristics are given in Table 4.

All of the macromolecules examined, except native cellulose, were hydrolyzed by the cytophaga. Gelatin, casein, litmus milk, and peptone were strongly hydrolyzed. Cellulose was not degraded, but $500 \mathrm{ml}$ of carboxymethylcellulose was degraded completely within 5 days. Alginate was neither utilized as a sole carbon source nor degraded in the presence of yeast extract. Catalase, indoxyl acetate esterase, and deoxyribonuclease were produced, but cytochrome oxidase and urease were not. Ornithine and lysine decarboxylases and phenylalanine deaminase were not produced; tyrosine was hydrolyzed very slowly. Tributyrin and Tweens 40,60 , and 80 were all hydrolyzed, although the hydrolysis of these lipids was slow in most cases. $\mathrm{H}_{2} \mathrm{~S}$ was not produced in iron peptone agar and the IMViC tests were negative.

Conditions for optimum growth of this organism are as follows: temperature, $20^{\circ} \mathrm{C}$ (range 5 to $35^{\circ} \mathrm{C}$ ); $\mathrm{pH}, 6.5$ (range 5.5 to 11.0 ); and $\mathrm{NaCl}$ concentration, $0 \%$ (tolerance up to $2 \%$ ). Most carbohydrates and alcohols tested were fermented within 3 to 4 days of inoculation, and the reactions were complete within 7 days (Table 5). Nitrate was reduced to $\mathrm{NH}_{3}$; ammonium nitrogen or nitrate could serve as the sole $\mathrm{N}$ sources.

Actinomycin D, aureomycin, bacitracin, chloramphenicol, erythromycin, kanamycin, nalidixic acid, neomycin, novobiocin, oleandomycin, streptomycin, sulfathiazole, tetracycline, and triple sulfas were inhibitory at the strengths listed in Table 6. Vancomycin inhibited gliding, but it did not inhibit growth.

As shown in Table 7, all bacteria tested, except Micrococcus lysodeikticus strain 4710 and Gaffkya tetragena strain 4731 , were lysed by strain $\mathrm{N}$. However, none of the blue-green algae tested were lysed. Sarcina lutea 4745 and Streptococcus faecalis 410216 were lysed most rapidly by the cytophaga.

The cell envelope was typical of gram-negative organisms (7), and some flexibility of the cell wall was evident (Fig. 3). Division was by transverse binary fission with septa forming between dividing rods. The guanine-plus-cytosine $(\mathrm{G}+\mathrm{C})$ content of the deoxyribonucleic acid was found by M. Mandel to be $33.7 \mathrm{~mol} \%$ for strain $\mathrm{N}$. The major pigments were not carotenoid but instead were similar to the polyene-chromophoric compounds found in Flexibacter elegans and other cytophagas $(17,18)$. The absorption spectra for the pigments in acetone and ethanol solvent systems and the bathochromic shift observed with the addition of $\mathrm{NaOH}$ in ethanol are given in Fig. 4. The color of the shifted pigments changed from yellow to red-violet and could be returned to the original spectrum by the addition of excess $\mathrm{HCl}$ in ethanol (18). The pigment could not be extracted from ether by using $\mathrm{Na}_{2} \mathrm{CO}_{3}$; it resisted photooxidation and gave a reddish color with the addition of $\mathrm{KOH}$ in methanol. The pigments did not give a sky-blue color with the presence of saturated $\mathrm{SbCl}_{3}$ in chloroform, but they gave a deep violet reaction when 


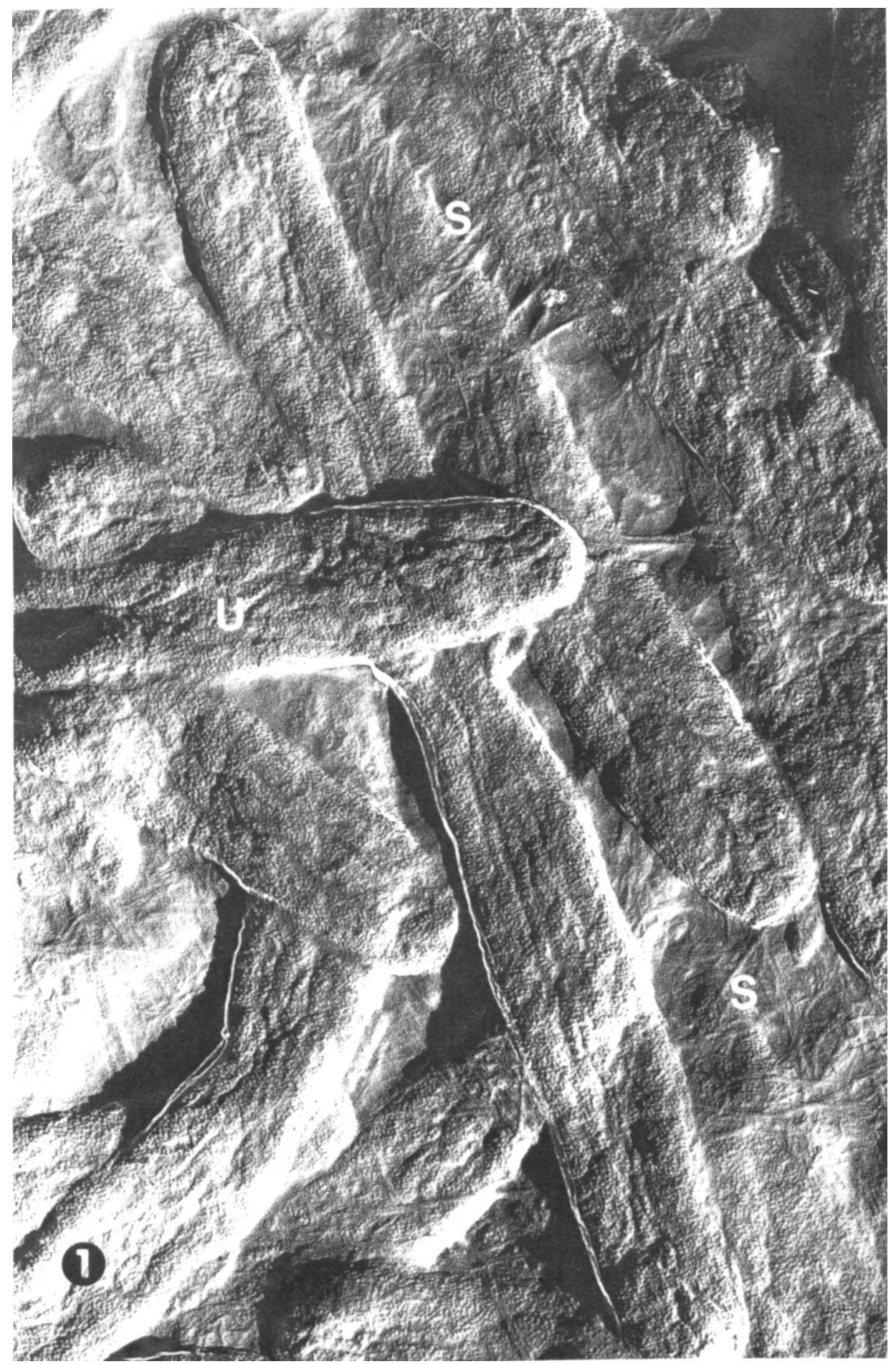

Fig. 1. Frozen-surface replica of strain $N$. Note the fibrillar nature of the slime (S) and the undulated surface $(U)$ of the cells. Magnification, $\times 43,500$. 


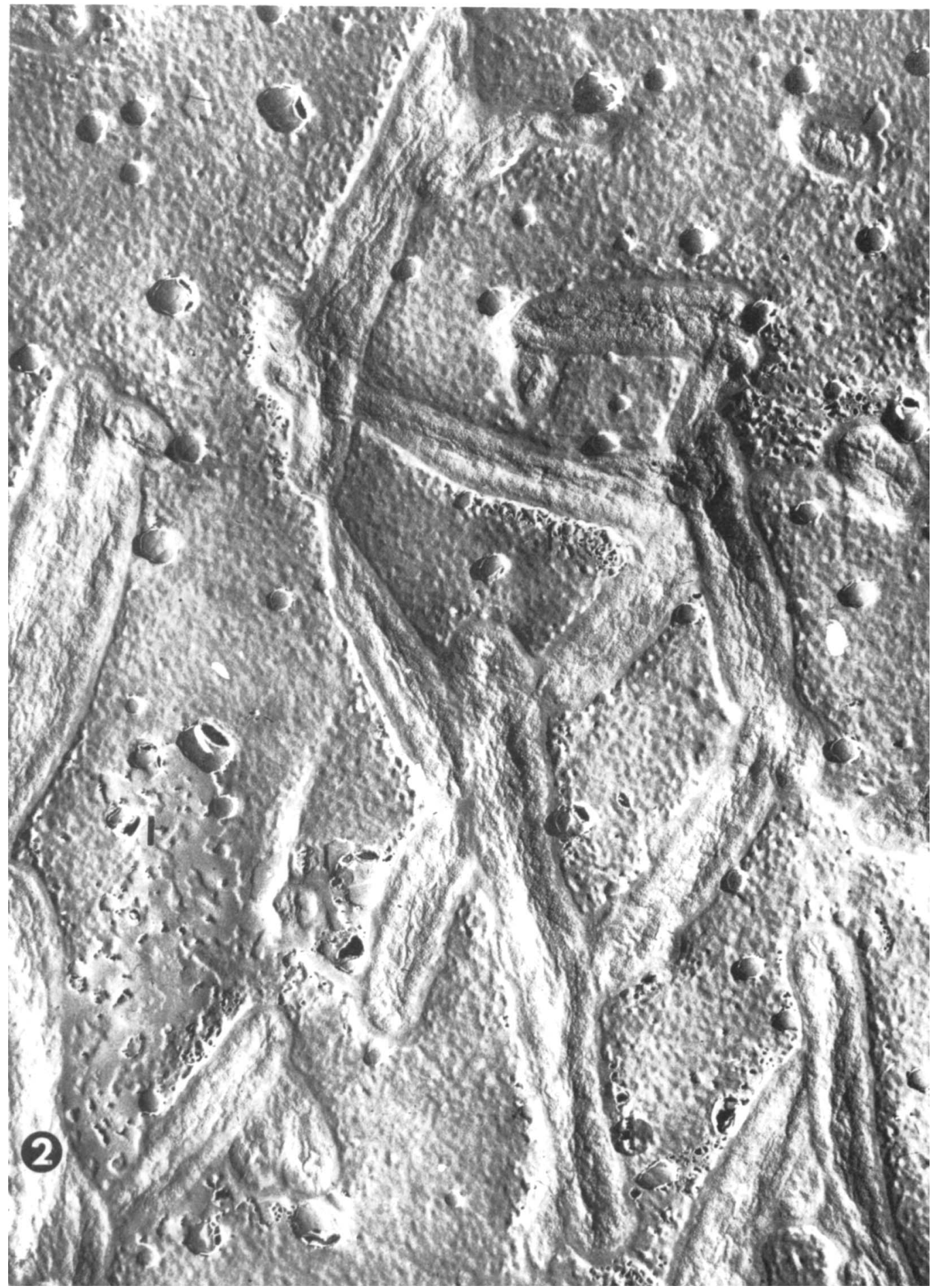

Fig. 2. Frozen-surface replica from colony edge of strain $N$ showing cells "etched" into agar surface and forming tonguelike extensions radiating from the colony center. Note ice-crystal damage in close proximity to cells (I). The bottom of the micrograph is towards the center of the colony. Magnification, $\times 25,000$. 
TABLE 2. General characteristics of the five strains studied

\begin{tabular}{|c|c|c|c|c|c|}
\hline \multirow{2}{*}{ Characteristic } & \multicolumn{5}{|c|}{ Reaction $^{a}$} \\
\hline & Strain $\mathrm{T}$ & Strain R & Strain $O$ & Strain Q & Strain N \\
\hline Gliding motility & + & + & + & + & + \\
\hline Microcysts $\ldots \ldots \ldots \ldots$ & - & - & - & - & - \\
\hline Fruiting bodies $\ldots \ldots \ldots \ldots$ & - & - & - & - & - \\
\hline Spreading colony $\ldots \ldots \ldots$ & + & + & + & + & + \\
\hline \multicolumn{6}{|l|}{ Colony pigments: } \\
\hline $2 \%$ Tryptone & $\mathrm{y}, \mathrm{o}, \mathrm{p}, \mathrm{b}$ & $y, o, p, b$ & $\mathrm{y}, \mathrm{o}, \mathrm{p}, \mathrm{b}$ & $y, o, p, b$ & $y, o, p, b$ \\
\hline Nutrient agar $\ldots \ldots \ldots$ & $0, \mathrm{~b}$ & $o, b$ & $0, b$ & $\mathrm{o}, \mathrm{b}$ & $o, b$ \\
\hline $\mathrm{CP}$ medium $\ldots \ldots \ldots$ & $\mathrm{y}$ & $\mathrm{y}$ & $\mathrm{y}$ & $\mathrm{y}$ & $\mathrm{y}$ \\
\hline Autolysis in old cultures $\ldots$ & + & + & + & + & + \\
\hline Anaerobic growth ........... & + & + & + & + & + \\
\hline Nitrate reduced to $\mathrm{NH}_{3} \ldots \ldots$ & + & + & + & + & + \\
\hline Growth at $4^{\circ} \mathrm{C} \ldots \ldots \ldots$ & - & - & - & - & - \\
\hline Cellulose degradation $\ldots \ldots \ldots$ & - & - & - & - & - \\
\hline Chitin degradation $\ldots \ldots \ldots$ & + & - & - & - & + \\
\hline Starch hydrolysis . . . . . . . . & + & + & + & + & + \\
\hline Casein hydrolysis $\ldots \ldots \ldots$ & + & + & + & + & + \\
\hline Gelatin hydrolysis $\ldots \ldots \ldots$ & + & + & + & + & + \\
\hline Peptone utilization $\ldots \ldots$ & + & + & + & + & + \\
\hline Catalase production $\ldots \ldots$ & + & + & + & + & + \\
\hline $\mathrm{H}_{2} \mathrm{~S}$ production $\ldots \ldots \ldots$ & - & - & - & - & - \\
\hline Indole production $\ldots \ldots \ldots$ & - & - & - & - & - \\
\hline Citrate utilization $\ldots \ldots \ldots$ & - & - & - & - & - \\
\hline Glucose oxidation ${ }^{b} \ldots \ldots \ldots$ & + & + & + & + & + \\
\hline Galactose oxidation $\ldots \ldots \ldots$ & - & - & - & - & - \\
\hline Sucrose oxidation $\ldots \ldots \ldots$ & - & - & - & - & - \\
\hline Cellobiose oxidation $\ldots \ldots \ldots$ & - & - & - & - & - \\
\hline Lactose oxidation $\ldots \ldots \ldots$ & - & - & - & - & - \\
\hline Maltose oxidation $\ldots \ldots \ldots$ & + & + & + & + & + \\
\hline Mannitol oxidation .......... & - & - & - & - & - \\
\hline
\end{tabular}

" Abbreviations and symbols: b, brown; o, orange; $p$, purple; y, yellow; + , positive result; - , negative result.

${ }^{b}$ Acid produced in 6 days.

treated with concentrated sulfuric acid. With the exception of negative reactions with $50 \%$ ethanolamine in ethanol and in the $\mathrm{SbCl}_{3}$ reaction, the pigments appeared similar to the flexirubin pigment found in $F$. elegans (18).

\section{DISCUSSION}

The unicellular gliding bacterium was placed in the genus Cytophaga because of its gliding motility, its lack of microcyst or fruiting-body production, its $33.7 \mathrm{~mol} \% \mathrm{G}+\mathrm{C}$ base ratio, its weak degradation of chitin, and its strong depolymerization of carboxymethylcellulose. It is different from any presently known species of $C y$. tophaga due to a combination of its fermentative and nitrate-reducing abilities, its freshwater origin, its starch, lipid, and strong protein hydrolytic capabilities, its production of catalase, and its lack of cytochrome oxidase. The only other fermentative freshwater member of the family Cytophagaceae is Flexibacter succinicans (2), formerly known as Cytophaga succinicans, which was also isolated from fish. Our cytophaga differs greatly from $F$. succinicans in chitin and carboxymethylcellulose depolymerization, $\mathrm{G}+\mathrm{C}$ base ratio, proteolytic capabilities, and in the requirement by $F$. succinicans of $\mathrm{CO}_{2}$ for fermentation of carbohydrates.

Our fermentative cytophaga is similar, however, to many isolates reported by various researchers (Table 8). Borg (3) reported four strains of fermentative cytophagas which differ from our cytophaga only in their inability to hydrolyze gelatin. Pacha and Porter (14) isolated several strains of saprophytic cytophagas, including six fermentative strains, from the surfaces of freshwater fish. These differ very little from our organism and may well be considered as strains of $C$. aquatilis. Bullock (4) studied many strains of cytophaga-like bacteria from fish. Among his 55 strains were three facultatively anaerobic strains capable of carrying out fermentation of glucose. These strains appear to be identical to our organism, and Reichardt (16) reported a strain "S-K," isolated from a freshwater habitat, which appears to be similar to our fermentative cytophaga. However, with the limited knowledge available about this organism, it is impossible to determine its relationship to $C$. aquatilis. All of these organisms are similar in 
TABle 3. Physiologic characteristics of strain $N$

\begin{tabular}{|c|c|}
\hline Test & Result \\
\hline $\begin{array}{l}\text { Deoxyribonucleic acid base composition } \\
\text { (mol\% } \mathbf{G}+\mathrm{C} \text {; buoyant density) }\end{array}$ & 33.7 \\
\hline Salinity tolerance $(\%) \ldots \ldots \ldots \ldots$ & $0-2.0$ \\
\hline Temp range for optimal growth $\left({ }^{\circ} \mathrm{C}\right)$ & $20-25$ \\
\hline Upper temp limit for growth $\left({ }^{\circ} \mathrm{C}\right)$ & 35 \\
\hline Lower temp for growth $\left({ }^{\circ} \mathrm{C}\right)$ & 5 \\
\hline $\mathrm{pH}$ range for growth & $5.5-11.0$ \\
\hline pH for optimal growth & 6.5 \\
\hline Nitrate reduction to $\mathrm{NH}_{3}$ & + \\
\hline Nitrogen fixation $\ldots \ldots$ & - \\
\hline Sodium dodecyl sulfate tolerance $(0.01 \%)$ & - \\
\hline Litmus milk reaction $\ldots \ldots \ldots \ldots \ldots$ & Hard curd \\
\hline Utilization of $\mathrm{NH}_{4}$-nitrogen & + \\
\hline Citrate utilization $\ldots \ldots \ldots$ & - \\
\hline Methyl red test & - \\
\hline Indole production & - \\
\hline Acetylmethylcarbinol production $\ldots$. & - \\
\hline $\mathbf{H}_{2} \mathbf{S}$ production $\ldots \ldots \ldots \ldots \ldots$ & - \\
\hline Catalase & + \\
\hline Cytochrome oxidase & - \\
\hline Urease ........... & - \\
\hline Deoxyribonuclease & + \\
\hline Indoxyl acetate esterase $\ldots \ldots \ldots \ldots$ & + \\
\hline Lysine decarboxylase $\ldots \ldots \ldots \ldots \ldots$ & - \\
\hline Phenylalanine deaminase $\ldots \ldots \ldots \ldots$ & - \\
\hline Ornithine decarboxylase $\ldots \ldots \ldots \ldots$ & - \\
\hline Blood hemolysis & - \\
\hline Tributyrin hydrolysis $\ldots \ldots \ldots \ldots \ldots$ & + \\
\hline Tween 40 hydrolysis . ..... & + \\
\hline Tween 60 hydrolysis & + \\
\hline Tween 80 hydrolysis . . . & + \\
\hline Pectin hydrolysis . . . . . . & + \\
\hline Tyrosine hydrolysis & + \\
\hline Gelatin hydrolysis & + \\
\hline Casein hydrolysis & + \\
\hline Esculin hydrolysis & + \\
\hline Alginate hydrolysis & - \\
\hline Starch hydrolysis $\ldots$ & + \\
\hline Glycogen hydrolysis & + \\
\hline Agar hydrolysis & - \\
\hline Cellulose degradation & - \\
\hline Carboxymethylcellulose digestion & + \\
\hline Chitin degradation $\ldots \ldots \ldots \ldots \ldots$ & + , weak \\
\hline
\end{tabular}

that they were isolated from fish or aquatic habitats. Those that were tested hydrolyzed chitin but not cellulose, fermented glucose, lacked cytochrome oxidase, were indole negative, hydrolyzed gelatin, starch, casein, and tributyrin, were catalase positive, and had an optimum temperature of about 20 to $25^{\circ} \mathrm{C}$ (Table 8).

The production of $\mathrm{H}_{2} \mathrm{~S}$ was detected in only the strains of Pacha and Porter, nitrate reduction was variable among the strains, and tyrosine degradation was variable with the strains of Pacha and Porter and of Bullock. Isolation and more complete characterization of additional strains may show that these factors are variable in the species. At this point, however, character-
TABLE 4. Morphological characteristics of the five strains studied

\begin{tabular}{|c|c|}
\hline Characteristic & Result \\
\hline Fruiting bodies present & $-(0 / 5)$ \\
\hline Microcysts present & $-(0 / 5)$ \\
\hline Cells in trichomes & $-(0 / 5)$ \\
\hline Cells in sheath & $-(0 / 5)$ \\
\hline Cells in filaments & $-(0 / 5)$ \\
\hline Helical forms present & $-(0 / 5)$ \\
\hline Branching present & $-(0 / 5)$ \\
\hline sts present & $+(5 / 5)$ \\
\hline tion & $-(0 / 5)$ \\
\hline Carotenoids as major pigments & - (strain N) \\
\hline Pigment peak (acetone solvent) & \\
\hline & 446 \\
\hline ers (nm) & $429,461,473$ \\
\hline ce at $260 \mathrm{~nm}$ & - (strain $N)$ \\
\hline ells $(\mu \mathrm{m})$ & $5-15(5 / 5)$ \\
\hline lls $(\mu \mathrm{m})$ & $0.5-1.0(5 / 5)$ \\
\hline on by septation & $+(5 / 5)$ \\
\hline esent & $-(0 / 5)$ \\
\hline Glic & $+(5 / 5)$ \\
\hline agar & $+(5 / 5)$ \\
\hline etched ir & $+(5 / 5)$ \\
\hline m-red-positive slime present & $+($ strain $\mathrm{N})$ \\
\hline cells . . . . . . . . . . . & $+(5 / 5)$ \\
\hline eposits & $-(0 / 5)$ \\
\hline Polysaccharide deposits & $+(5 / 5)$ \\
\hline Poly- $\beta$-hydroxybutyrate deposits $\ldots$ : & $-(0 / 5)$ \\
\hline
\end{tabular}

TABLE 5. Oxidative and fermentative production of acid from carbohydrates and alcohols by strain $N^{a}$

\begin{tabular}{|c|c|c|}
\hline Substrate & Oxidation & $\begin{array}{c}\text { Fermen- } \\
\text { tation }\end{array}$ \\
\hline \multicolumn{3}{|l|}{ Carbohydrate } \\
\hline Glucose & + & + \\
\hline Galactose & W & + \\
\hline$\ldots \ldots \ldots \ldots$ & W & + \\
\hline 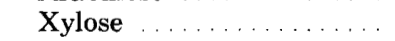 & W & + \\
\hline$\ldots \ldots \ldots \ldots$ & W & + \\
\hline Trehalose $\ldots \ldots \ldots \ldots$ & W & \\
\hline Fructose $\ldots \ldots \ldots \ldots$ & W & + \\
\hline$\ldots \ldots \ldots \ldots$ & W & + \\
\hline$\ldots \ldots \ldots$ & W & + \\
\hline . & - & - \\
\hline$\ldots \ldots \ldots \ldots$ & W & + \\
\hline$\ldots \ldots \ldots \ldots$ & V & W \\
\hline Cellobiose $\ldots \ldots \ldots \ldots$ & W & + \\
\hline \multicolumn{3}{|l|}{ Alcohol } \\
\hline Glycerol & V & + \\
\hline Dulcitol & $\mathrm{V}$ & + \\
\hline Sorbitol & - & - \\
\hline Mannitol & W & + \\
\hline$\ldots \ldots \ldots \ldots$ & - & - \\
\hline
\end{tabular}

${ }^{a}$ Symbols: + , positive, acid formed within 6 days; $\mathrm{W}$, weakly positive, acid formed after 7 days; -, negative; $\mathrm{V}$, variable.

istics of our five strains and the additional tests on strain $\mathrm{N}$ should constitute the description of the species. 
TABLE 6. Antibiotic susceptibility of strain N

\begin{tabular}{|c|c|c|}
\hline Antibiotic & Dosage & Inhibition \\
\hline Actinomycin $\mathrm{D} \ldots \ldots$ & $100 \mu \mathrm{g}$ & + \\
\hline Ampicillin $\ldots \ldots \ldots \ldots$ & $10 \mu \mathrm{g}$ & - \\
\hline Aureomycin $\ldots \ldots \ldots \ldots$ & $30 \mu \mathrm{g}$ & + \\
\hline Bacitracin . & $10 \mathrm{U}$ & + \\
\hline Chloramphenicol ....... & $30 \mu \mathrm{g}$ & + \\
\hline Colymycin & $10 \mu \mathrm{g}$ & - \\
\hline Erythromycin . . . . . . . & $15 \mu \mathrm{g}$ & + \\
\hline Kanamycin & $30 \mu \mathrm{g}$ & + \\
\hline Lincomycin & $2 \mu \mathrm{g}$ & - \\
\hline Methicillin & $5 \mu g$ & - \\
\hline Nalidixic acid & $30 \mu \mathrm{g}$ & + \\
\hline Neomycin ... & $30 \mu \mathrm{g}$ & + \\
\hline Novobiocin & $30 \mu \mathrm{g}$ & + \\
\hline Oleandomycin $\ldots \ldots \ldots$ & $15 \mu \mathrm{g}$ & + \\
\hline Penicillin $\mathbf{G} \ldots \ldots \ldots$ & $10 \mathrm{U}$ & - \\
\hline Polymyxin B & $300 \mathrm{U}$ & - \\
\hline Streptomycin & $10 \mu \mathrm{g}$ & + \\
\hline Sulfadiazine . & $300 \mu \mathrm{g}$ & - \\
\hline Sulfathiazole $\ldots \ldots \ldots \ldots$ & $1 \mathrm{mg}$ & + \\
\hline Tetracycline & $30 \mu \mathrm{g}$ & + \\
\hline Triple sulfa & $1 \mathrm{mg}$ & + \\
\hline Vancomycin & $30 \mu \mathrm{g}$ & $-{ }^{a}$ \\
\hline
\end{tabular}

${ }^{a}$ Inhibits gliding.

It may be noted that only three out of Bullock's 55 strains were fermentative, yet all of his freshwater isolates showed a striking consistency among the basic physiological tests. It is very possible that a glucose-oxidative, strictly aerobic species of Cytophaga or Flexibacter exists which is similar to the fermentative cytophaga.

Because all five of our strains were isolated from gills of fish displaying symptoms of bacterial gill disease, it is possible that these organisms were pathogenic to those fish under the prevailing environmental conditions. Since no tests were devised to test this hypothesis, it cannot be determined if the cytophagas were the disease-causing organisms. Anderson and Conroy (1) and Bullock (4) have suggested that aquatic "myxobacteria" should be considered as opportunistic pathogens, only producing gill disease when the fish are stressed by environmental conditions. Since Trust (22) found that cytophagas are part of the normal gill flora of healthy salmon, he concluded also that environmental conditions must "predispose the gill to pathological changes by these organisms" common to the fish and that it acts as an opportunistic invader when the fish are placed under stressed conditions. Since hatchery-raised fish are often stressed due to factors such as overcrowding, temperature, and low dissolved-oxygen tension, it is possible that the salmon are killed off by pathogenic effects produced by the cytophagas under these conditions. Much more research must be done in this area with similar organisms to provide further understanding of the ecology of the disease.

Surface-replica preparations (Fig. 1 and 2) showed that the cytophaga has an undulated surface and produces great amounts of slime, which probably facilitates the gliding motility of these organisms. The cells at the colony edge are "etched" into the agar with zones of icecrystal damage around the cells (Fig. 1). It is possible that these ice-crystal zones are due to the formation of water released into the medium during hydrolysis of nutrients. That idea provides an explanation as to why ice-crystal damage is seen only in close proximity to the cells. Further ultrastructural analysis of the cytophaga will be published elsewhere (W. R. Strohl and L. R. Tait, manuscript in preparation).

The major pigments have been found to be similar to the "flexirubin" pigment found in $F$. elegans (18). Reichenbach (personal communication) has indicated that these pigments are common to freshwater cytophagas. They were formerly thought to be carotenoids $(2,11,12)$. In the past, determination of cytophaga pigments as carotenoids was usually done by using the absorption spectra and the cyanolipid $\mathrm{H}_{2} \mathrm{SO}_{4}$ test. Since neither of these tests distinguishes flexirubin-like pigments from carotenoids, it should become standard procedure to utilize further screening tests such as the $\mathrm{KOH}$ in ethanol spectral shift and the $50^{\circ} \mathrm{C}-\mathrm{NaBH}_{4}$-induced bathochromic shift as proposed by Reichenbach et al. (18).

We regard our five isolates (strains $T, R, O$., $\mathrm{Q}$, and $\mathrm{N}$ ) as belonging to a new species, for which we propose the name Cytophaga aquatilis. A formal description of the species is given below with a description of the type strain. Many of the species characteristics are based on one

TABLE 7. Lysis of microogranisms by strain $N$

\begin{tabular}{|c|c|}
\hline Test organism & Lysis \\
\hline Rhodospirillum rubrum $1221^{a}$ & + \\
\hline Escherichia coli 4411 & + \\
\hline Serratia marcescens 4471 & + \\
\hline Proteus mirabilis 4482 & + \\
\hline Micrococcus lysodeikticus 4710 & - \\
\hline Staphylococcus epidermidis 4722 & + \\
\hline Sarcina lutea $4745 \ldots \ldots \ldots$ & + \\
\hline Streptococcus faecalis 410216 & + \\
\hline Clostridium perfringens $42 \mathrm{CP} 3$ & + \\
\hline Caulobacter sp. CP4 . . . . . & + \\
\hline Gaffkya tetragena 4731 & - \\
\hline Plectonema boryanum BPB1 & - \\
\hline Anacystis nidulans BAN1 & - \\
\hline Nostoc sp. BNS1 & - \\
\hline
\end{tabular}

${ }^{a}$ Strain numbers are those of the Department of Biology, Central Michigan University, Mount Pleasant, Mich. 


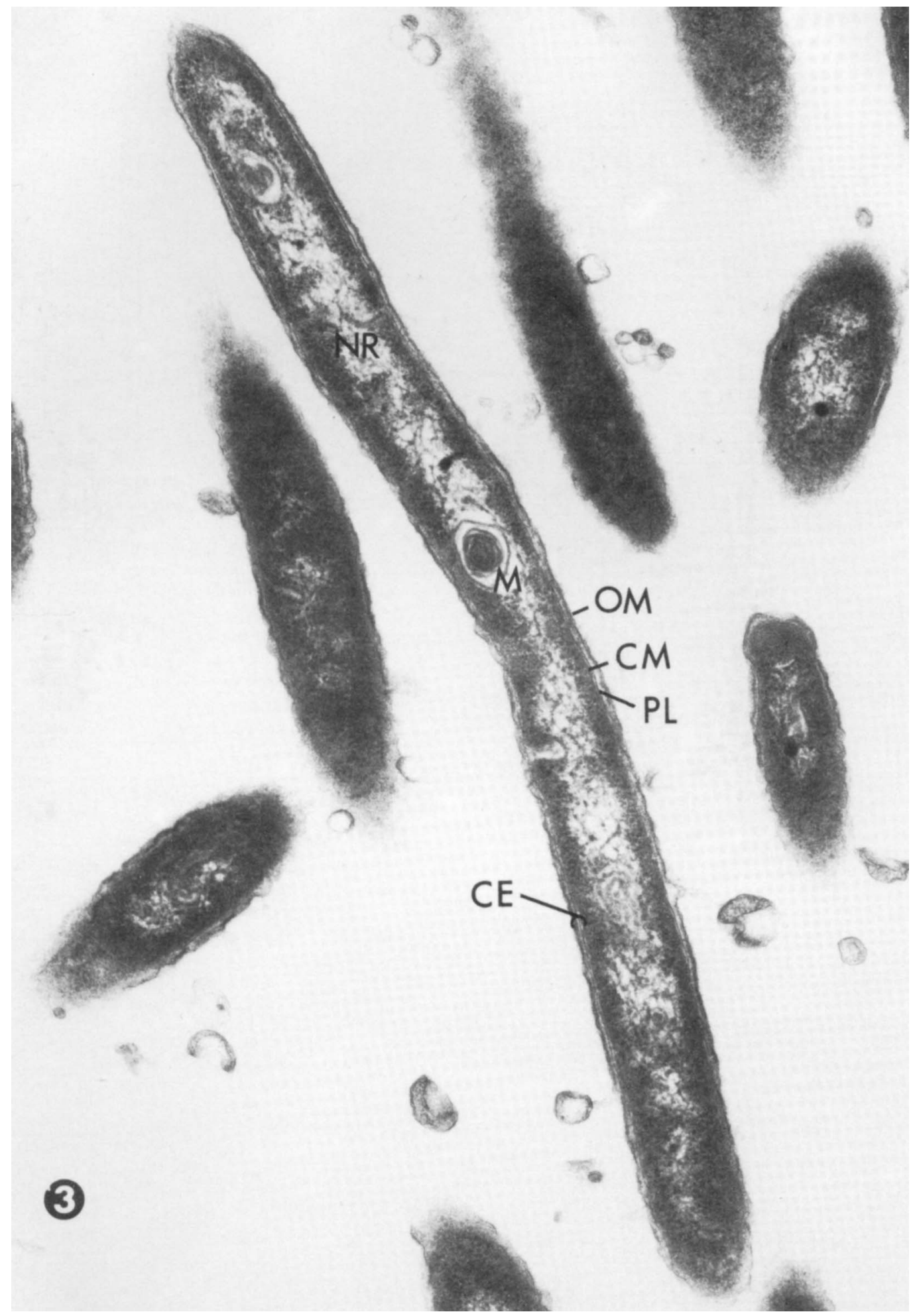

FIG. 3. Thin-section micrograph of strain $N$ showing typical gram-negative cell envelope (CE) with the cytoplasmic membrane (CM), peptidoglycan layer (PL), and lipopolysaccharide outer membrane (OM). Note the well developed mesosomes $(M)$ and nuclear region (NR). Magnification, $\times 40,000$. 


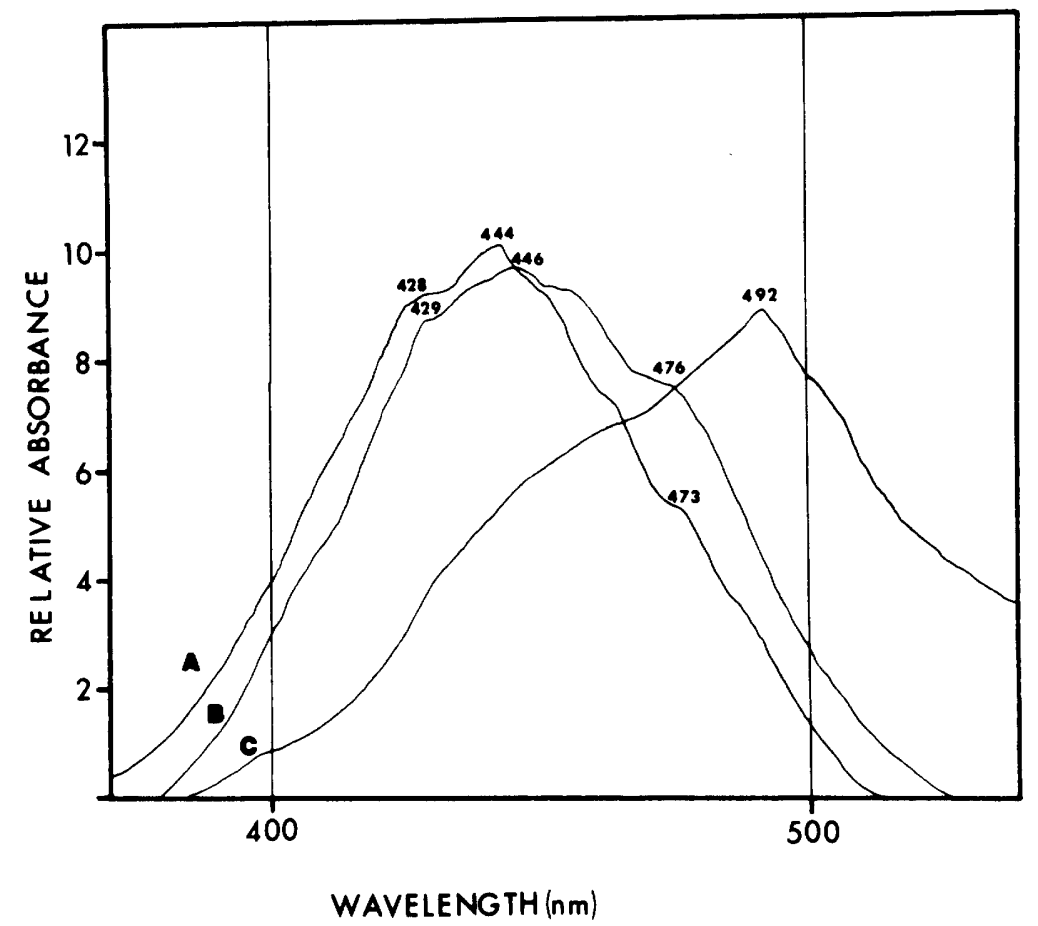

FIG. 4. Absorption spectra of strain-N pigments in ethanol (A) and acetone (B). Bathochromic shift induced by the addition of $\mathrm{NaOH}$ in ethanol is shown as $(\mathrm{C})$.

TABLE 8. Comparison of strain $N$ with some other facultatively anaerobic cytophagas isolated from fish or water $^{a}$

\begin{tabular}{|c|c|c|c|c|c|}
\hline Test & Strain N & $\begin{array}{l}\text { Borg's iso- } \\
\text { lates (2) }\end{array}$ & $\begin{array}{l}\text { Pacha and } \\
\text { Porter's iso- } \\
\text { lates (14) }\end{array}$ & $\begin{array}{l}\text { Bullock's } \\
\text { isolates }^{h} \text { (14) }\end{array}$ & $\begin{array}{l}\text { Reichardt's } \\
\text { isolate (16) }\end{array}$ \\
\hline Cellulose degradation $\ldots \ldots \ldots \ldots$ & - & - & - & - & - \\
\hline Chitin decomposition $\ldots \ldots \ldots \ldots \ldots$ & + & & + & & + \\
\hline Starch hydrolysis & + & + & + & + & + \\
\hline Gelatin liquefaction $\ldots \ldots \ldots \ldots \ldots$ & + & - & + & + & + \\
\hline Indole production $\ldots \ldots \ldots \ldots \ldots$ & - & - & - & - & - \\
\hline Casein hydrolysis & + & + & + & + & \\
\hline Nitrate reduction & + & + & V & + & $\mathrm{V}$ \\
\hline $\mathrm{H}_{2} \mathrm{~S}$ production & - & & + & - & \\
\hline Tributyrin hydrolysis $\ldots \ldots \ldots \ldots$ & + & & + & + & \\
\hline Catalase production $\ldots \ldots \ldots \ldots \ldots$ & + & + & + & + & \\
\hline Urease production & - & - & & & \\
\hline Cytochrome oxidase $\ldots \ldots \ldots \ldots$ & - & - & - & - & \\
\hline Esculin hydrolysis $\ldots \ldots \ldots \ldots \ldots$ & + & & + & & \\
\hline Tyrosine hydrolysis $\ldots \ldots \ldots \ldots \ldots$ & + & & $\mathrm{V}$ & $\mathrm{V}$ & \\
\hline Anaerobic growth & + & + & + & + & + \\
\hline Glucose fermentation $\ldots \ldots \ldots \ldots$ & + & + & + & + & + \\
\hline Pectin hydrolysis $\ldots \ldots \ldots \ldots \ldots \ldots$ & + & & & & \\
\hline Bacteriolysis & + & & + & + & \\
\hline Optimal temp 20 to $25^{\circ} \mathrm{C} \ldots \ldots \ldots$ & + & + & + & + & + \\
\hline
\end{tabular}

${ }^{a}$ Symbols: + , positive; - , negative; $\mathrm{V}$, variable.

${ }^{b}$ Three fermentative strains $(4.53,4.26$, and 4.7$)$.

strain (strain $\mathrm{N}$ ) although several of the distinguishing factors are based on five strains.

Cytophaga aquatilis sp. nov. (a. qua'ti. lis. L. adj. aquatilis living in water). The following characteristics are based on five strains. Flexible rods, 0.5 to $0.75 \mu \mathrm{m}$ in diameter, 5 to $15 \mu \mathrm{m}$ in length. Gram negative. Motile by gliding; aflagellate. Both elongated and coccoid forms are 
present in old cultures, the latter superficially resembling microcysts. Chitin may be weakly hydrolyzed (two of five strains are positive), but cellulose and agar are not. Starch, casein, gelatin, and peptone are hydrolyzed. Catalase is produced, but $\mathrm{H}_{2} \mathrm{~S}$ and indole are not. Citrate is not utilized. Nitrate is reduced to ammonia and can be used as a sole $\mathrm{N}$ source. Acid is produced from glucose and maltose oxidatively but not from sucrose, cellobiose, lactose, galactose, or mannitol. Anaerobic growth occurs in the presence of glucose and yeast extract or during nitrate reduction. Colonies are pigmented yellow or orange to light brown when grown aerobically and are nonpigmented under anaerobic conditions. Additional characteristics of strain $\mathrm{N}$ are listed below. Alginate is not used as a carbon and energy source. Carboxymethylcellulose is strongly hydrolyzed. Deoxyribonuclease and indoxyl acetate esterase are produced, but cytochrome oxidase and urease are not. Acetylmethylcarbinol is not produced; the methyl red test is negative. Tweens 40,60 , and 80 , and tributyrin are hydrolyzed and are used as sole carbon sources. Strongly bacteriolytic but not cyanobacteriolytic. Ferments and weakly oxidizes a wide range of carbohydrates and alcohols. The $\mathrm{G}+\mathrm{C}$ content of the deoxyribonucleic acid is 33.7 $\mathrm{mol} \%$ (based on a buoyant-density analysis). The major pigments produced resemble flexirubin and are not carotenoid. The temperature for optimal growth is $20^{\circ} \mathrm{C}$; no growth occurs at 0 or $37^{\circ} \mathrm{C}$.

Type strain. The only strain of the species now available, strain $\mathrm{N}$, is designated as the type strain; a culture of this strain has been deposited with the American Type Culture Collection under the accession number 29551.

\section{ACKNOWLEDGMENTS}

We thank Manley Mandel for analyzing the deoxyribonucleic acid of strain $\mathrm{N}$ and Russell Steere for the use of his laboratory and his technical assistance in preparing the frozensurface replicas. We also thank Ellis Brockman and James Lampky for their cooperation, patience, and helpful assistance throughout this investigation and John Larkin for his assistance in the preparation of this manuscript.

\section{REPRINT REQUESTS}

Address reprint requests to: William R. Strohl, Dept. of Microbiology, 508 Life Sciences Building, Louisiana State University, Baton Rouge, LA 70803.

\section{LITERATURE CITED}

1. Anderson, J. I. W., and D. A. Conroy. 1969. The pathogenic myxobacteria with special reference to fish diseases. J. Appl. Bacteriol. 32:30-39.

2. Anderson, R. L., and E. J. Ordal. 1961. Cytophaga succinicans sp. n., a facultatively anaerobic, aquatic myxobacterium. J. Bacteriol. 81:130-138.

3. Borg, A. F. 1960 . Studies on myxobacteria associated with diseases in salmonoid fishes. Wildl. Dis. 8:1-85.

4. Bullock, G. L. 1972. Studies on selected myxobacteria pathogenic for fishes and on bacterial gill disease in hatchery-reared salmonoids. Technical paper 60. U.S. Department of the Interior, Bureau of Sport Fisheries and Wildlife, Washington, D.C.

5. Carlson, R. V., and R. E. Pacha. 1968. Procedure for the isolation and enumeration of myxobacteria from aquatic habitats. Appl. Microbiol. 16:795-796.

6. Christensen, P. J., and F. D. Cook. 1972. The isolation and enumeration of cytophagas. Can. J. Microbiol. 18:1933-1940.

7. Costerton, J. W., J. M. Ingram, and K. J. Cheng. 1974. Structure and function of the cell envelope of gram-negative bacteria. Bacteriol. Rev. 38:87-110.

8. Difco Laboratories. 1953. Difco manual. Difco Laboratories, Inc., Detroit, Mich.

9. Dworkin, M., and S. M. Gibson. 1964. A system for studying microbial morphogenesis: rapid formation of microcysts in Myxococcus xanthus. Science 146:243-244.

10. Gromov, B. V., O. G. Ivanov, K. A. Mamkaeva, and I. A. Avilov. 1972. A flexibacter that lyses blue-green algae. Mikrobiologiya 41:1074-1079.

11. Leadbetter, E. R. 1974. Cytophagales, p. 99-127. In R. E. Buchanan and N. E. Gibbons (ed.), Bergey's manual of determinative bacteriology, 8 th ed. The Williams and Wilkins Co., Baltimore, Md.

12. Lewin, R. A., and D. M. Lounsbery. 1969. Isolation, cultivation, and characterization of flexibacteria. J. Gen Microbiol. 58:145-170.

13. Mollenhauer, H. H. 1963 . Plastic embedding mixtures for use in electron microscopy. J. Stain Technol. 39:111-114.

14. Pacha, R. E., and S. Porter. 1968. Characteristics of myxobacteria isolated from the surface of freshwater fish. Appl. Microbiol. 16:1901-1906.

15. Pate, J. L., and E. J. Ordal. 1967. The fine structure of Chondrococcus columnaris. I. Structure and formation of mesosomes. J. Cell Biol. 35:1-13.

16. Reichardt, W. 1974. Zur Okophysiologie einiger Gewasserbakterien aus der Flavobacterium-CytophagaGruppe. Zentralbl. Bakteriol. Parasitenkd. Infektionskr. Hyg. Abt. I Orig. 227:85-93.

17. Reichenbach, H., and H. Kleinig. 1972. Die Carotinoide der Myxobakterien. Zentralbl. Bakteriol. Parasitenkd. Infektionskr. Hyg. Abt. I Orig. 220:458-463.

18. Reichenbach, H., H. Kleinig, and H. Achenbach. 1974. The pigments of Flexibacter elegans: novel and chemosystematically useful compounds. Arch. Microbiol. 101:131-144.

19. Ryter, A., and E. Kellenberger. 1958. Etude au microscope electronique de plasmas contenant de l'acide desoxyribonucleique. I. Les nucleoides des bacteries en croissance active. Z. Naturforsch. 13b:597-605.

20. Shilo, M. 1970. Lysis of blue-green algae by myxobacter. J. Bacteriol. 104:453-461.

21. Steere, R. L. 1973. Preparation of high-resolution freezeetch, freeze-fracture, frozen-surface, and freeze-dried replicas in a single freeze-etch module, and the use of stereo electron microscopy to obtain maximum information from them. In E. L. Benedetti and P. Favard (ed.), Freeze-etching techniques and applications. Societe Francaise de Microscopie Electronique, Paris.

22. Trust, T. J. 1975. Bacteria associated with the gills of salmonoid fishes in freshwater. J. Appl. Bacteriol. 38:225-233. 